\title{
Growth of Indian Life Insurance Density and Penetration
}

\author{
R Sivarama Prasad* and R S N Sharma ${ }^{\dagger}$
}

\begin{abstract}
The Government of India nationalized insurance industry in 1956 on $19^{\text {th }}$ January to form the Life Insurance Corporation of India. The Life Insurance Corporation of India, a public sector corporation, enjoyed a monopoly in the business for four decades until the entry of private life insurers with foreign joint ventures having $26 \%$ Foreign Direct Investment (FDI). On 19 ${ }^{\text {th }}$ April 2000, Insurance Regulatory and Development Authority was set up by the Government of India through the passing of an act of the Parliament. Since its formation, the IRDA has been proving itself successful in promoting orderly growth and development in Indian Insurance sector. This study is an attempt to study life insurance density and penetration in Indian life Insurance industry to assess the growth in the expansion of life insurance business in India. An analysisis made, and some conclusions are drawn with the help of growth percentages and trend calculations.
\end{abstract}

Keywords: Life Insurance Density, Life Insurance Penetration, IRDA

\footnotetext{
* Acharya Nagarjuna University, Guntur, Andhra Pradesh, India; raminenisivaram@yahoo.co.in

tSt Theresa Degree College for Women, Eluru, Andhra Pradesh, India; ryalisivanag@gmail.com
} 


\section{Introduction}

Finance related services are services like banking, insurance etc. There are various types of risks: business risk, financial risk, natural calamities and so on. Human life is risky. Every moment and movement of human life may become risky. Unknowingly anything may happen to any person at anytime in any situation the effect of that unfavourable incident may cause death or partial or permanent disablement to the affected.

When the head of a family who is the bread winner to that family dies suddenly or becomes bedridden permanently due to some critical illness because of an accident or an unexpected event, the family members suffer. They may not be in a position to get their livelihood and may not able to fulfil their responsibilities like children's education, daughters' marriage etc. In this context life insurance is of great help to the dependent family members provided the head of the family had taken a life insurance policy. An agreed sum of money will be paid either on the maturity of the policy or death or disablement of the head of the family. With this amount, they can fulfil their responsibilities at least to some extent.

Insurance is giving assurance for recovery loss. When goods, properties and other valuable things are insured against risks like fire accidents etc.,it is classified as general insurance. If life policy is taken against death or disablement of a person, it is known as life insurance. There are two parties in any insurance transaction, Insurer and Insured. Whoever gives a guarantee is called the insurer and whoever takes the guarantee is called the insured. To commensurate the guarantor, the insured is required to pay a certain sum of money periodically which is called premium. The agreement between the two parties is the insurance contract.

\section{Insurance Penetration}

It is measured as a percentage of insurance premiums underwritten in a given year to the Gross Domestic Product (GDP).

\section{Insurance Density}

Insurance density is the per capita premium, which is calculated as a ratio of a premium underwritten in a given year to the total 
population. So it is a ratio of premium to the population. Thisis expressed in US dollars for international comparison.

In any country, the potential and performance of its insurance sector are assessedwith reference to two parameters. They are Insurance penetration and insurance density. These measures reflect the level of development of insurance sector in that country.

\section{Review of Literature}

According to Venkataramani, Kumar, Brinda (2015) the attitude of consumers and insurance agents toward the proposed increase in FDI indicates that the respondents welcomed the Government decision to increase FDI capital in insurance sector of India.

Aravind K. Singh, Mamta Singh (2014) analyzed the problems in attaining innovations and accelerating the growth rate of innovations in the insurance market.

\section{Objectives of the Study}

- To analyse Indian Life Insurance penetration since 2001 to 2013

- To evaluate Indian Life insurance density since 2001 to 2013

\section{Limitations of the study}

The total study is based on secondary data collected from the annual reports of LIC and IRDA and Handbooks of insurance statistics of IRDA. The available information is taken for study and analysis. The information not available for a few of the years included in the study period may change the analysis and results to some extent.

\section{Period of the study}

The period of the study is from 2001 to 2013. 


\section{Research Methodology}

Sample: India is taken as a sample to study and compare life insurance business with that of other countries in diagrams and conclusionsare drawn.

Data Sources: IRDA annual reports and Handbook of insurance statistics 2013-14, journals and websites of LIC and IRDA

\section{Methodology}

The present study is completely based on secondary data collected from annual reports and Handbook of insurance statistics 2013-14 of IRDA. The collected information is then analyzed with the help of growth percentages, tabulated and depicted. The total study is based on secondary data collected from annual reports of LIC and IRDA and Handbooks of insurance statistics of IRDA. Available information is taken for study and analysis. The information not available for a few years may change the analysis and results to some extent.

Table1 Insurance density and penetration in India

\begin{tabular}{|c|c|c|}
\hline Year & Density(used) & Penetration (\%) \\
\hline 2001 & 9.1 & 2.15 \\
\hline 2002 & 11.7 & 2.59 \\
\hline 2003 & 12.9 & 2.26 \\
\hline 2004 & 15.7 & 2.53 \\
\hline 2005 & 18.3 & 2.53 \\
\hline 2006 & 33.2 & 4.10 \\
\hline 2007 & 40.4 & 4.00 \\
\hline 2008 & 41.2 & 4.00 \\
\hline 2009 & 47.7 & 4.60 \\
\hline 2010 & 55.7 & 4.40 \\
\hline 2011 & 49.0 & 3.40 \\
\hline 2012 & 42.7 & 3.17 \\
\hline 2013 & 41.0 & 3.10 \\
\hline
\end{tabular}

Source: IRDA annual report 2013-14

*insurance density is the ratio of premium (in USD) to total population.

*Insurance penetration is the ratio of premium(in USD) to GDP(in USD) 


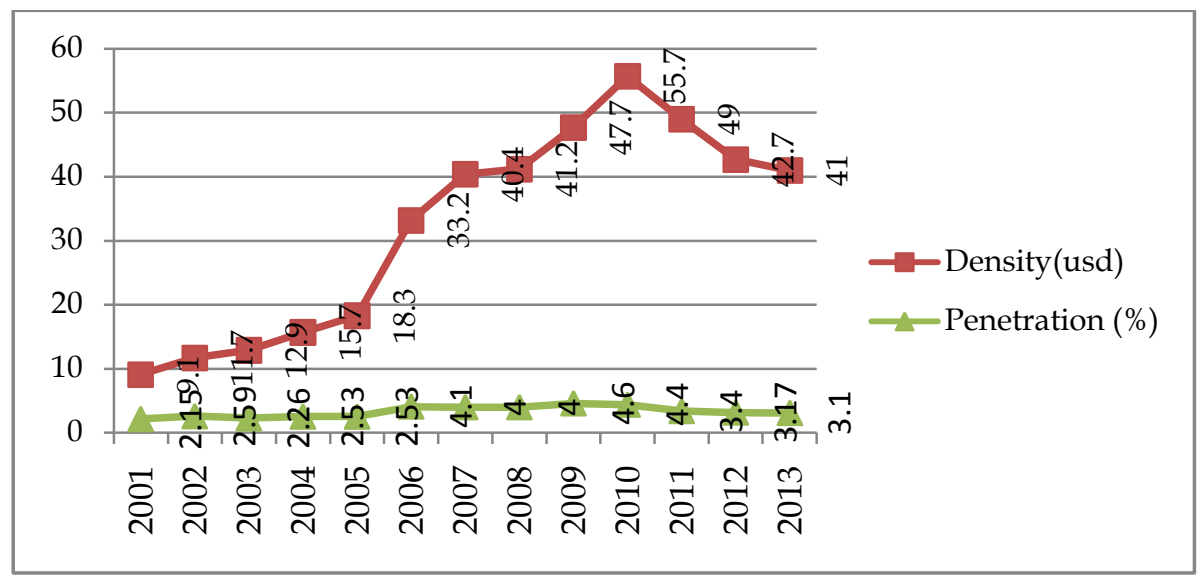

1 A Insurance density and penetration in India

Source: IRDA Handbook on Insurance Statistics -2013-14

\section{Analysis and Interpretation}

The above information (Table.1 and1.A) indicates that since 2001 both life insurance density and penetration have been increasing. The density has increased from 9.1(2001) to 55.7(2010) which is the highest. Later on declined in the following years to 41.0(2013).On the whole, it is in significant increasing trend. These premium amounts are being significantly improved with the performance of Insurance Regulatory and Development Authority. In the same way, penetration is also increasing consistently from 2.15 (2001) and reached to 4.60 in the year 2009 but later on declining. On the whole it is significant growth.

Table 2 Analysis of life insurance penetration in India and World

\begin{tabular}{rrrcrrr}
\hline Year & India & Growth\% & Index & World & Growth\% & Index \\
\hline 2001 & 2.15 & --- & 100.00 & 4.68 & --- & 100.00 \\
2002 & 2.59 & 20.47 & 120.47 & 4.76 & 1.71 & 101.71 \\
2003 & 2.26 & -12.74 & 105.12 & 4.59 & -3.57 & 98.08 \\
2004 & 2.53 & 11.95 & 117.67 & 4.55 & -0.87 & 97.22 \\
2005 & 2.53 & 0.00 & 117.67 & 4.34 & -4.62 & 92.74 \\
2006 & 4.10 & 62.06 & 190.70 & 4.50 & 3.69 & 96.15 \\
2007 & 4.00 & -2.44 & 186.05 & 4.40 & -2.22 & 94.02 \\
2008 & 4.00 & 0.00 & 186.05 & 4.10 & -6.82 & 87.61 \\
2009 & 4.60 & 15.00 & 213.95 & 4.00 & -2.44 & 85.47 \\
2010 & 4.40 & -4.35 & 204.65 & 4.00 & 0.00 & 85.47 \\
\hline
\end{tabular}




\begin{tabular}{llrllll}
\hline 2011 & 3.40 & -22.73 & 158.14 & 3.80 & -5.00 & 81.20 \\
2012 & 3.17 & -6.76 & 147.44 & 3.69 & -2.90 & 78.85 \\
2013 & 3.10 & -2.21 & 144.19 & 3.50 & -5.15 & 74.79 \\
\hline
\end{tabular}

Source: IRDA Handbook on Insurance Statistics -2013-14

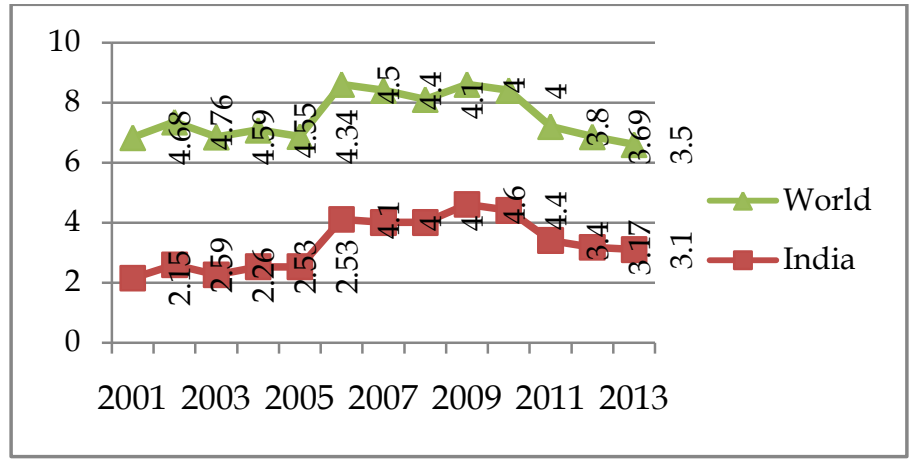

2A Analysis of life insurance penetration in India and World

Source: IRDA Handbook on Insurance Statistics -2013-14

\section{Analysis and Interpretation}

Growth\% is calculated by taking increased value in the following year basing on the previous value in per cent. All growth rates are increased or decreased percentage rates over that of previous years. The index value is considered as the value of the year (in percentage)over the value of first year of the study period. During the study period, overall index values show an increasing trend. The above information (Table.2 and2.A) indicates that Life insurance penetration in India in 2002 increased by $20.47 \%$ over the previous year 2001, decreased in the following year 2003, no increase or decrease in the year 2008.In the year, 2006 highest growth rate $62.06 \%$, lowest in 2011 i.e.-22.73are registered. On the whole, greater fluctuations are evident in growth rates of Indian life insurance penetration. On observing the index values it can be concluded that even if there are fluctuations, on an average they are in increasing trend. By taking the year 2001 as base as 100, it increased to 144.19 in the year 2013.

In case of world life insurance penetration, a Little growth in the year $2002(101.71 \%)$ and continuous declined rates can be observed in the following years till the last year of study,2013(74.79\%).On 
comparison of India's life insurance penetration with that of the world, though fluctuations are more and heavy in India overall growth rates are positive and in increasing trend.However, in the world, it is in continuous negative rates, and there is no overall improvement in the world average rates as they are in decreasing trend when compared to India with regard to life insurance penetration.Finally, it can be concluded that Life insurance penetration in India is an increasing trend at an increased rate and better than that of the world.

Table 3 Analysis of life insurance density in India and World

\begin{tabular}{ccccccc}
\hline Year & India & Growth $\%$ & Index & World & Growth $\%$ & Index \\
\hline 2001 & 9.1 & --- & 100.00 & 235.0 & --- & 100.00 \\
2002 & 11.7 & 28.57 & 128.57 & 247.3 & 5.23 & 105.23 \\
2003 & 12.9 & 10.26 & 141.76 & 267.1 & 8.01 & 113.66 \\
2004 & 15.7 & 21.71 & 172.53 & 291.5 & 9.14 & 124.04 \\
2005 & 18.3 & 16.56 & 201.10 & 299.5 & 2.74 & 127.45 \\
2006 & 33.2 & 81.42 & 364.84 & 330.6 & 10.38 & 140.68 \\
2007 & 40.4 & 21.69 & 443.96 & 358.1 & 8.32 & 152.38 \\
2008 & 41.2 & 1.98 & 452.75 & 369.7 & 3.24 & 157.32 \\
2009 & 47.7 & 15.78 & 524.18 & 341.2 & -7.71 & 145.19 \\
2010 & 55.7 & 16.77 & 612.09 & 364.3 & 6.77 & 155.02 \\
2011 & 49.0 & -12.03 & 538.46 & 378.0 & 3.76 & 160.85 \\
2012 & 42.7 & -12.86 & 469.23 & 372.6 & -1.43 & 158.55 \\
2013 & 41.0 & -3.98 & 450.55 & 366.0 & -1.77 & 155.74 \\
\hline
\end{tabular}

Source: IRDA Handbook on Insurance Statistics -2013-14

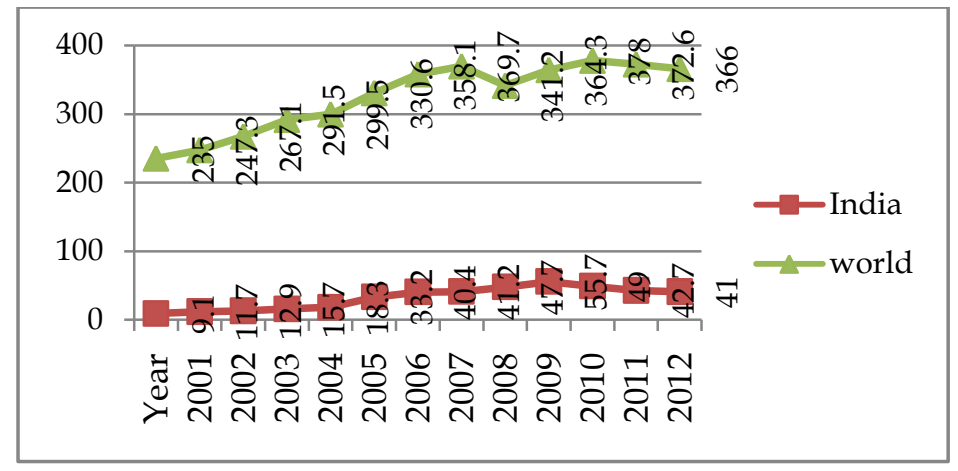

3A Analysis of life insurance density in India and World

Source: IRDA Handbook on Insurance Statistics -2013-14 


\section{Analysis and Interpretation}

Growth\% is calculated by taking increased value in the following year basing on the previous value in per cent. All growth rates are increased or decreased percentage rates over that of previous years. The index value is considered as that year value as a percentage of the value of the first year of the study period. During the study period, overall index values are in increasing trend.

The above information (Table. 3 and3.A) indicates that Life insurance density in India in 2002 increased by $28.57 \%$ over the previous year 2001, decreased in the following year 2003, very less positive growth rate $1.98 \%$ in the year 2008.In the year2006, highest growth rate $81.42 \%$, lowest in 2012i.e.--12.86\%.On the whole, greater fluctuations are evident in growth rates of Indian life insurance density. Index from 100 as a base in the year 2001 though rose to $612.09 \%$ in the year 2010 and decreased from there and came down to $450.55 \%$ in the year 2013.Irrespective of fluctuations positive overall growth can be observed in Indian life insurance density.

In case of world's life insurance density it has been increasing and decreasing. Growth rates highest $10.38 \%$ in the year 2006 and lowest i.e. negative $-7.71 \%$ in the year 2009 can be observed. Negative rates-1.43\% (2012) and-1.77\% (2013) are also registered. When indexis taken into consideration, the $160.85 \%$ (2011) is higher but has faced a little bit of a decline in the later years. Overall growth is in increasing trend. On comparison of India's life insurance density with that of world, it can be concluded that India is comparatively in a better position.

On comparison of India's life insurance penetration with that of the world, fluctuations are more and heavy in India but less in the World. Overall improvement is more in India when compared to the world with regard to life insurance penetration. 
Table 4 Analysis of life insurance penetration in India and other top countries

\begin{tabular}{|c|c|c|c|c|c|c|c|c|c|c|c|c|c|c|c|}
\hline Year & India & $\begin{array}{c}\text { Growth } \\
\%\end{array}$ & Index & $\begin{array}{l}\text { South } \\
\text { Africa }\end{array}$ & $\begin{array}{c}\text { Growth } \\
\%\end{array}$ & Index & Taiwan & $\begin{array}{c}\text { Growth } \\
\%\end{array}$ & Index & UK & $\begin{array}{c}\text { Growth } \\
\%\end{array}$ & Index & $\begin{array}{l}\text { Hong } \\
\text { Kong }\end{array}$ & $\begin{array}{c}\text { Growth } \\
\%\end{array}$ & Index \\
\hline 2001 & 2.15 & --- & 100 & 15.19 & --- & 100 & 6.03 & & 100 & 10.73 & & 100 & 5.13 & & 100 \\
\hline 2002 & 2.59 & 20.47 & 120.47 & 15.92 & 4.81 & 104.81 & 7.35 & 21.89 & 121.89 & 10.19 & -5.03 & 94.97 & 5.20 & 1.36 & 101.36 \\
\hline 2003 & 2.26 & -12.74 & 105.12 & 12.96 & -18.59 & 85.32 & 8.28 & 12.65 & 137.31 & 8.62 & -15.41 & 80.34 & 6.38 & 22.69 & 124.37 \\
\hline 2004 & 2.53 & 11.95 & 117.67 & 11.43 & -11.81 & 75.25 & 11.06 & 33.57 & 183.42 & 8.92 & 3.48 & 83.13 & 7.88 & 23.51 & 153.61 \\
\hline 2005 & 2.53 & 0.00 & 117.67 & 10.84 & -5.16 & 71.36 & 11.17 & 0.99 & 185.24 & 8.90 & -0.22 & 82.95 & 8.63 & 9.52 & 168.23 \\
\hline 2006 & 4.10 & 62.06 & 190.70 & 13.00 & 19.93 & 85.58 & 11.60 & 3.85 & 192.37 & 13.10 & 47.19 & 122.09 & 9.20 & 6.60 & 179.34 \\
\hline 2007 & 4.00 & -2.44 & 186.05 & 12.50 & -3.85 & 82.29 & 12.90 & 11.21 & 235.32 & 12.60 & -3.82 & 117.43 & 10.60 & 15.22 & 206.63 \\
\hline 2008 & 4.00 & 0.00 & 186.05 & 12.50 & 0.00 & 82.29 & 13.30 & 3.10 & 220.56 & 12.80 & 1.59 & 119.29 & 9.90 & -6.60 & 192.98 \\
\hline 2009 & 4.60 & 15.00 & 213.95 & 10.00 & -20.00 & 65.83 & 13.80 & 3.76 & 228.86 & 10.00 & -21.88 & 93.20 & 9.60 & -3.03 & 187.13 \\
\hline 2010 & 4.40 & -4.35 & 204.65 & 12.00 & 20.00 & 79.00 & 15.40 & 11.59 & 255.39 & 9.50 & -5.00 & 88.54 & 10.10 & 5.21 & 196.88 \\
\hline 2011 & 3.40 & -22.73 & 158.14 & 10.20 & -15.00 & 67.15 & 13.90 & -9.74 & 230.51 & 8.70 & -8.42 & 81.08 & 10.10 & 0.00 & 196.88 \\
\hline 2012 & 3.17 & -6.76 & 147.44 & 11.56 & 13.33 & 76.10 & 15.03 & 8.13 & 249.25 & 8.44 & -2.99 & 78.66 & 11.02 & 9.11 & 214.81 \\
\hline 2013 & 3.10 & -2.21 & 144.19 & 12.70 & 9.86 & 83.61 & 14.50 & -3.53 & 240.46 & 8.80 & 4.27 & 82.01 & 11.70 & 6.17 & 228.07 \\
\hline
\end{tabular}

Source: IRDA Handbook on Insurance Statistics -2013-14 


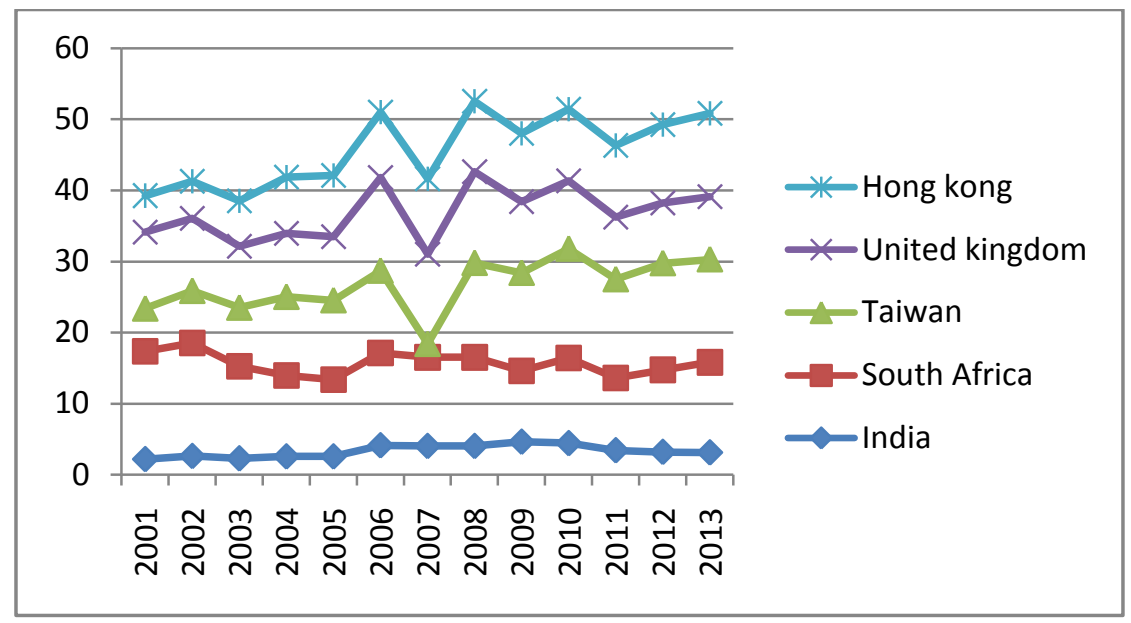

4A Analysis of life insurance penetration in India and other top countries

Source: IRDA Handbook on Insurance Statistics -2013-14

\begin{tabular}{|l|l|l|l|}
\hline \multicolumn{1}{|c|}{ Year } & \multicolumn{1}{|c|}{ Japan } & \multicolumn{1}{c|}{ Growth $\%$} & \multicolumn{1}{c|}{ Index } \\
\hline 2001 & 2806.4 & & 100 \\
\hline 2002 & 2783.9 & -0.80 & 99.20 \\
\hline 2003 & 3002.9 & 7.87 & 107.00 \\
\hline 2004 & 3044.0 & 1.37 & 108.47 \\
\hline 2005 & 2956.3 & -2.88 & 105.34 \\
\hline 2006 & 2829.3 & -4.30 & 100.82 \\
\hline 2007 & 2583.9 & -8.67 & 92.07 \\
\hline 2008 & 2869.5 & 11.05 & 102.25 \\
\hline 2009 & 3138.7 & 9.38 & 111.84 \\
\hline 2010 & 3472.8 & 10.65 & 123.75 \\
\hline 2011 & 4138.0 & 19.16 & 147.45 \\
\hline 2012 & 4142.5 & 0.11 & 147.61 \\
\hline 2013 & 3346.0 & -19.23 & 119.23 \\
\hline
\end{tabular}

\section{Analysis and Interpretation}

Growth\% is calculated by taking increased value in the following year basing on the previous value in per cent. All growth rates are increased or decreased percentage rates over that of previous years. The index value is considered as that year value as a percentage of the value of the first year of the study period. Life insurance penetration growth rates in India range between $-4.35 \%(2010)$ and 
Table 5 Analysis of life Insurance Density in India and other top countries

\begin{tabular}{|c|c|c|c|c|c|c|c|c|c|c|c|c|}
\hline Year & India & Growth\% & Index & UK & $\begin{array}{c}\text { Growth } \\
\%\end{array}$ & Index & France & $\begin{array}{c}\text { Growth } \\
\%\end{array}$ & Index & $\begin{array}{c}\text { Switzer } \\
\text { land }\end{array}$ & $\begin{array}{c}\text { Growth } \\
\%\end{array}$ & Index \\
\hline 2001 & 9.1 & --- & 100 & 2567.9 & --- & 100 & 1268.2 & & 100 & 2715.7 & --- & 100 \\
\hline 2002 & 11.7 & 28.57 & 128.57 & 2679.4 & 4.34 & 104.34 & 1349.5 & 6.41 & 106.41 & 3099.7 & 14.14 & 114.14 \\
\hline 2003 & 12.9 & 10.26 & 141.76 & 2617.1 & -2.33 & 101.92 & 1767.9 & 31.00 & 139.40 & 3431.8 & 10.71 & 126.37 \\
\hline 2004 & 15.7 & 21.71 & 172.53 & 3190.4 & 21.91 & 124.24 & 2150.2 & 21.63 & 169.55 & 3275.1 & -4.57 & 120.60 \\
\hline 2005 & 18.3 & 16.56 & 201.10 & 3287.1 & 3.03 & 128.01 & 2474.6 & 15.09 & 195.13 & 3078.1 & -6.02 & 113.34 \\
\hline 2006 & 33.2 & 81.42 & 364.84 & 5139.6 & 56.36 & 200.15 & 2922.5 & 18.10 & 230.44 & 3111.8 & 1.09 & 114.59 \\
\hline 2007 & 40.4 & 21.69 & 443.96 & 5730.5 & 11.50 & 223.16 & 2928.3 & 2.00 & 230.90 & 3159.1 & 1.52 & 116.33 \\
\hline 2008 & 41.2 & 1.98 & 452.75 & 5582.1 & -2.59 & 217.38 & 2791.9 & -4.66 & 220.15 & 3551.5 & 12.42 & 130.78 \\
\hline 2009 & 47.7 & 15.78 & 524.18 & 3527.6 & -36.81 & 137.37 & 2979.8 & 6.73 & 234.96 & 3405.6 & -4.11 & 125.40 \\
\hline 2010 & 55.7 & 16.77 & 612.09 & 3436.3 & -2.59 & 133.82 & 2937.6 & -1.42 & 231.64 & 3666.8 & 7.67 & 135.02 \\
\hline 2011 & 49.0 & -12.03 & 538.46 & 3347.0 & -2.60 & 130.34 & 2638.0 & -10.20 & 208.01 & 4421.0 & 20.57 & 162.79 \\
\hline 2012 & 42.7 & -12.86 & 469.23 & 3255.8 & -2.73 & 126.79 & 2239.2 & -15.12 & 176.57 & 4121.1 & -6.78 & 151.75 \\
\hline 2013 & 41.0 & -3.98 & 450.55 & 3474.0 & 6.70 & 135.29 & 2391.0 & 6.78 & 188.53 & 4211.0 & 2.18 & 155.06 \\
\hline
\end{tabular}

Source: IRDA Handbook on Insurance Statistics -2013-14 
$62.06 \%$ (2006).Index is indicating that overall growth based on 100 in the year 2001 is in an increasing trend and reached finally to $144.19 \%$ in the last year of the study period, 2013. In South Africa, these are ranging in between-20.00\%(2009) and 20.00\%(2009).Index is indicating that overall growth based on 100 in the year 2001 is in an increasing trend in some years and in decreasing trend in some years and reached finally to $83.61 \%$ in the last year of the study period, 2013. In Taiwan, these range between $-9.74 \%(2011)$ and $33.57 \%(2004)$.Index is indicating that overall growth based on 100 in the year 2001 is in increasing trend and reached finally to $240.46 \%$ in the last year of study period, 2013.

In United Kingdom, these range between $-8.42 \%(2011)$ and $47.19 \%(2006)$.Index indicates that overall growth based on 100 in the year 2001 is in increasing trend though decreased in some years reached finally to $82.01 \%$ in the last year of the study period, 2013.In Hong Kong these are ranging in between $-6.60 \%(2008)$ and $23.51 \%(2004)$. The index is indicating that overall growth based on 100 in the year 2001 is in increasing trend though decreased in some years reached finally to $228.07 \%$ in the last year of the study period, 2013.From the above-selected countries in comparison with regard to overall growth index rates, as far as Life insurance penetration is concerned Taiwan $(240.46 \%)$ is in the first place, followed by Hong Kong $(228.07 \%)$ in the second place and India(144.19\%)in third place. Countries like South Africa (83.61\%) and United Kingdom (82.01\%) are placed in the fourth and fifth position respectively. When actual visible values are considered, India has a lower life insurance penetration values; South Africa and Taiwan have higher values. These are depicted in the following diagram.

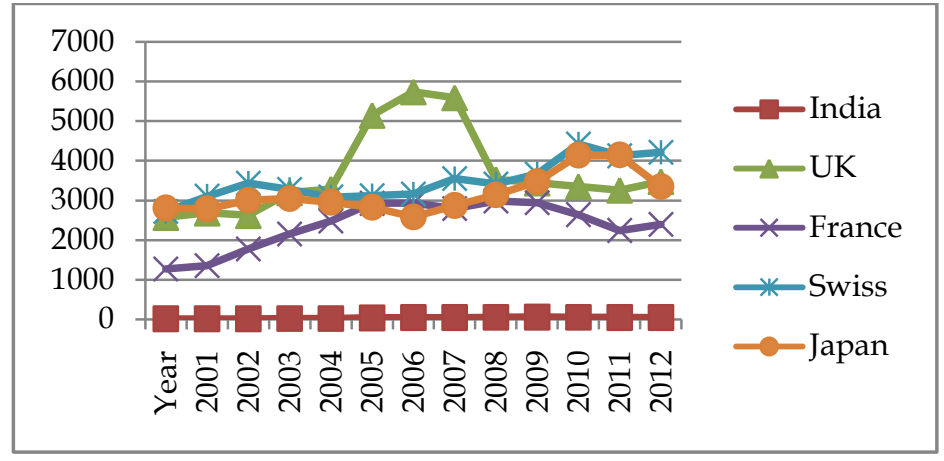

5A Life insurance density in US \$

Source: IRDA Handbook on Insurance Statistics -2013-14 
Table.6 Life insurance companies operating in India on 31 ${ }^{\text {st }}$ March 2014

\begin{tabular}{|c|c|c|c|c|c|}
\hline $\begin{array}{l}\text { Sl. } \\
\text { No }\end{array}$ & $\begin{array}{c}\text { Reg. } \\
\text { No }\end{array}$ & $\begin{array}{c}\text { Name of the company } \\
\text { Private Sector Life insurers }\end{array}$ & $\begin{array}{c}\text { Date of } \\
\text { Registration }\end{array}$ & Foreign Partner & $\begin{array}{c}\text { Year of } \\
\text { operation }\end{array}$ \\
\hline 1 & 138 & AEGON Religare Life Insurance Co. Ltd. & $27-06-2008$ & Aegon, India Holdings, BV Netherlands & 2008-09 \\
\hline 2 & 122 & Aviva Life Insurance Co. Ltd. & 14-05-2002 & Aviva International Holdings ltd, UK & 2002-03 \\
\hline 3 & 116 & Bajaj Allianz Life Insurance Co. Ltd. & 03-08-2001 & Allianz, SE Germany & 2001-02 \\
\hline 4 & 130 & Bharti AXA Life Insurance Co. Ltd. & 14-07-2006 & AXA India holdings, France & 2006-07 \\
\hline 5 & 109 & Birla Sun Life Insurance Co. Ltd. & 31-01-2001 & Sun Life Financial (India) Insurance Investment Inc, Canada & 2001-02 \\
\hline 6 & 136 & Canara HSBC OBC Life Insurance Co. Ltd. & 08-05-2008 & HSBC Insurance (Asia Pacific) Holdings Ltd & 2008-09 \\
\hline 7 & 140 & DLF Pramerica Life Insurance Company Ltd... & 27-06-2008 & Prudential International Insurance Holdings Ltd. USA & 2008-09 \\
\hline 8 & 147 & Edelweiss Tokio Life Insurance Company Ltd. & 10-05-2011 & Tokio Marine \& Nichido Fire Insurance Company Ltd. Japan & 2011-12 \\
\hline 9 & 114 & ING Life Insurance Company Ltd. & 02-08-2001 & ------------ & 2001-02 \\
\hline 10 & 133 & Future Generali Life Insurance Co. Ltd. & 04-09-2007 & $\begin{array}{l}\text { Participate Maatschapij Graafsschap Holland NV, } \\
\text { Netherlands }\end{array}$ & 2007-08 \\
\hline 11 & 101 & HDFC Standard Life Insurance Co. Ltd & $23-10-2000$ & Standard Life (Mauritius Holdings) 2006, Ltd. UK & 2000-01 \\
\hline 12 & 105 & ICICI Prudential Life Insurance Co. Ltd. & 24-11-2000 & Prudential Corporation Holdings Ltd. UK & 2000-01 \\
\hline 13 & 135 & IDBI Federal Life Insurance Co. Ltd. & 19-12-2007 & Ageas Insurance International NV Netherlands & 2007-08 \\
\hline 14 & 143 & IndiaFirst Life Insurance Co. Ltd. & 05-11-2009 & Legal \& General Middle East Ltd. & 2009-10 \\
\hline 15 & 107 & Kotak Mahindra Old Mutual Life Insurance Co. Ltd & 10-01-2001 & Old Mutual Plc, South Africa & 2001-02 \\
\hline 16 & 104 & Max Life Insurance Co. Ltd. & $15-11-2000$ & Mitsui Sumitomo Insurance Company Ltd. Japan & 2000-01 \\
\hline 17 & 117 & PNB MetLife India Insurance Co. Ltd. & 06-08-2001 & Metlife International Holdings Inc, USA & 2001-02 \\
\hline 18 & 121 & Reliance Life Insurance Co. Ltd. & 03-01-2002 & Nippon Life Insurance Company Ltd. Japan & 2001-02 \\
\hline 19 & 127 & Sahara India Life Insurance Co. Ltd. & 06-02-2004 & ------- & 2004-05 \\
\hline 20 & 111 & SBI Life Insurance Co. Ltd. & 29-03-2001 & BNP Paribas Assure SA, France & 2001-02 \\
\hline 21 & 128 & Shriram Life Insurance Co. Ltd. & 17-11-2005 & ------ & 2005-06 \\
\hline 22 & 142 & Star Union Dai-ichi Life Insurance Co. Ltd & 26-12-2008 & Dai-ichi Mutual life ins,Japan & 2008-09 \\
\hline 23 & 110 & TATA AIA Life Insurance Co. Ltd. & $12-02-2001$ & American Internll Assurance Company (Bermuda Ltd.) & 2001-02 \\
\hline 24 & 512 & $\begin{array}{l}\text { Life Insurance Corporation of India } \\
\text { (Public Sector) }\end{array}$ & 01-09-1956 & ------------- & $1956-57$ \\
\hline
\end{tabular}

IRDA Handbook on Insurance Statistics -2012-13 (as on 30thSeptember 2013) Source: IRDA Handbook on Insurance Statistics -2013-14 
Table 7 Registered Insurers in India(on 30-09-2014)

\begin{tabular}{llll}
\hline \multicolumn{1}{c}{ Type of Business } & Private Sector & Public Sector & Total \\
\hline Life insurance & 1 & 23 & 24 \\
Non-life insurance & 6 & 22 & 28 \\
Reinsurance & 1 & 0 & 1 \\
Total & 8 & 45 & 53 \\
\hline
\end{tabular}

Source: IRDA Annual report 2013-14

As on 30th September 2014,(Table 6and7) there are totally 53 insurance companies in India of which 24 companies are Life Insurance companies, 28 non-life insurance companies and one reinsurance company. Out of total 24 Life insurance companies, Life Insurance Corporation of India is working under public sector and the remaining 23 life insurance companies are private Life insurers.

Table 8 Analysis of growth in number of life insurance offices in India

\begin{tabular}{lcrrrr}
\hline Year & $\begin{array}{c}\text { LIC } \\
\text { (Number) }\end{array}$ & $\begin{array}{c}\text { Private Sector } \\
\text { (Number) }\end{array}$ & $\begin{array}{c}\text { Industry } \\
\text { (Number) }\end{array}$ & $\begin{array}{r}\text { \% of } \\
\text { growth }\end{array}$ & Index \\
\hline 2001 & 2186 & 13 & 2199 & --- & 100 \\
2002 & 2190 & 116 & 2306 & 4.87 & 104.87 \\
2003 & 2191 & 254 & 2445 & 6.03 & 111.19 \\
2004 & 2196 & 416 & 2612 & 6.83 & 118.78 \\
2005 & 2197 & 804 & 3001 & 14.89 & 136.47 \\
2006 & 2220 & 1645 & 3865 & 28.79 & 175.76 \\
2007 & 2301 & 3072 & 5373 & 39.02 & 244.34 \\
2008 & 2522 & 6391 & 8913 & 65.88 & 405.32 \\
2009 & 3030 & 8785 & 11815 & 32.56 & 537.29 \\
2010 & 3250 & 8768 & 12018 & 1.72 & 546.52 \\
2011 & 3371 & 8175 & 11546 & -3.93 & 525.06 \\
2012 & 3455 & 7712 & 11167 & -3.28 & 507.82 \\
2013 & 3526 & 6759 & 10285 & -7.90 & 467.71 \\
2014 & 4839 & 6193 & 11032 & 7.26 & 501.68 \\
\hline
\end{tabular}

Source: IRDA Handbook of Insurance Statistics-2010-11 and 2012-13,2013-14 reports

Growth $\%$ is calculated by taking increased value in the following year basing on the previous value in per cent. All growth rates are increased percentage rates over that of previous years. The index value is considered as that year value as a percentage of the value of the first year of the study period. During the study period, overall index values are in increasing trend 


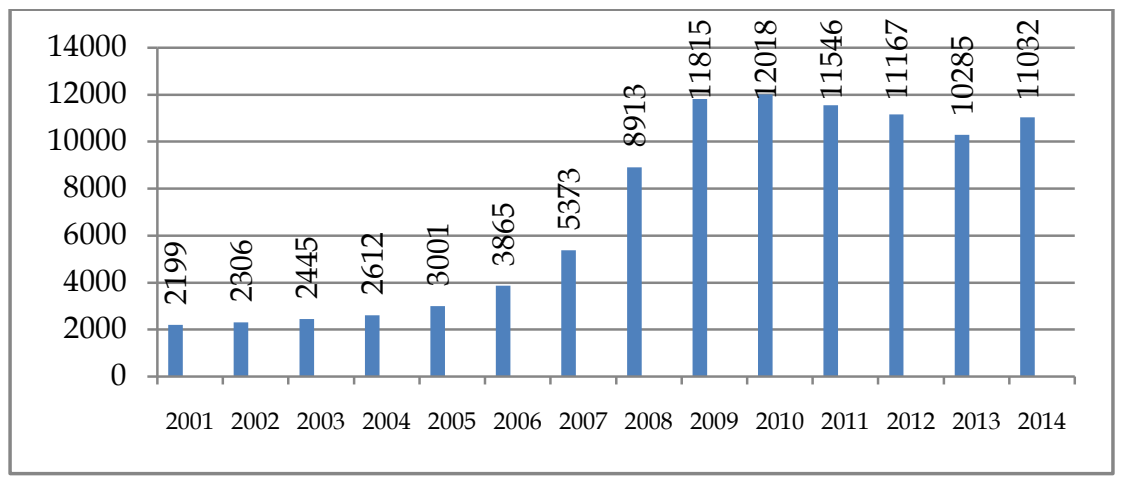

8A Number of life insurance offices in India

Source: IRDA Handbook on Insurance Statistics -2013-14

\section{Analysis and Interpretation}

The above information (Table 7 and $7 \mathrm{~A}$ ) reveals that the number of life insurance offices in India has been increasing since 2001 after the establishment of Insurance Regulatory and Development Authority. Starting with 2199 offices in the year 2001, the number increased to the 12018 maximum numbers of offices since then declined in the years 2011 to 2013, and in the year 2014, it started increasing. The maximum growth rate in $2008(65.88 \%)$ and negative growth rates in the years in the years, 2011 to 2013 were registered. On the whole, it is in significant increasing trend. The index values indicate that starting with 100 as a base in the year 2001 till 2014 the number increased to $501.68 \%$.

Causes for the above improvements in the Indian Life insurance industry (historical background)

To control, regulate, and develop insurance business and to safeguard the interests and rights of consumers, IRDA was established on 19th April of the year 2000.

\section{Insurance Regulatory and Development Authority (IRDA):}

Started functioning with this mission statement:

- To set, promote, monitor, and enforce high standards of integrity, financial soundness, fair dealing and competence of those it regulates. 
- To ensure speedy settlement of genuine claims, to prevent insurance funds and other malpractices and put in place effective grievance redressal machinery.

- To promote fairness, transparency and orderly conduct in financial markets dealing with insurance and build a reliable management information system to enforce high standards of financial soundness amongst market players.

- To take action where such standards are inadequate or ineffectively enforced.

- To bring about optimum amount of self-regulation in day to day working of the industry consistent with the requirements of the prudential regulation.

\section{Milestones}

- 1999 - the IRDA Act was passed

- 2000 - Formation of IRDA and framing of various regulations on 19April, 2000. Entry of private life insurers and foreign companies into the Indian insurancemarket.

- 2001 - Establishment of insurance councils, introducing TPAs for servicing health insurance policies, for life and non-life file and use procedures

- 2002 - regulations for the protection of interests of policyholders, introduction of new insurance intermediaries-brokers, corporate agents

- 2003 - referral arrangement with banks, strengthening insurance councils

- 2004 - strengthening investment framework, various committees/working groups on issues earthquake pool, health insurance and intermediaries, sales illustrations - life insurance business, standards of practices

- 2005 - KPN committee on provisions of Insurance Act, 1938; Micro insurance Regulations: Guidelines on group insurance policies: De-tariffing of Marine insurance; Guidelines for unit linked insurance products. 
- 2006 - Road map for de-trifling of general insurance; Entry of Stand-Alone Health Insurance Company; Guidelines on Anti-Money Laundering/Counter Financing of terrorism (AML/CFT); new file \&use guide lines for non-life product filing.

- 2007 - Creation of Motor pool for Third Party Insurance; Guidelines on Advertisement, Promotion and publicity of Insurance companies and Insurance intermediaries; Detariffing of the general insurance sector.

- 2008 - Benefit illustrations for Unit-linked products; strengthening on-site and off-site monitoring; innovations in products.

- 2009 - Grievance Redressal Mechanism; Guidelines for corporate governance; Guidelines for Health plus life combo product.

- 2010 - Mandating public disclosures; IRDA Regulations (Sharing of database for distribution of insurance products); Treatment of discontinued Linked policies regulations; Creation of IRDA Grievance call centre guidelines for Grievance redressed.

- 2011 - IRDA Regulations 2011(Issuance of capital by Life insurance companies);Portability of health insurance policies; Mobile application to compare insurance products and premium rates; IRDA's Insurance awareness initiative' Bima Bemisaal'; Creation of IGMS(Integrated Grievance Management System)

- 2012 - Revised ULIP guidelines; Creation of Consumer Education Website-for public; Web Enabled facility to ascertain insurance particulars of Motor vehicles; Online application to compare nonlife insurance products.

- 2013 - IRDA Regulations 2013(Issuance of Capital by General Insurance companies); Launching of Insurance Repository System for Individual policyholders; IRDA Health insurance regulations; IRDA Linked and NonLinked Life Insurance Regulations; IRDA(places of Business) Regulations, 2013; Introducing Common Service 
Centers as New Intermediary Insurance Fraud Monitoring Framework.

\section{Findings}

- Insurance Regulatory and Development Authority played a very significant role in improving insurance density and penetration levels in India

- Insurance density in India started increasing from 9.1 in the year 2001 and reached 55.7 in the year 2010 and later on it has decreased from the year 2011and is 41.0 in the last year 2013 of the study period.

- In comparisonwith regard to overall growth index rates, as far as Life insurance Density is concerned, India (450.55\%) is in first; France (188.53\%) in second; Switzerland (155.06\%)in third positions.

- Insurance penetration in India also started increasing from 2.15 in the year 2001 and reached 4.60 in the year 2009 and getting decreased in the later years and it is 3.1 in the last year 2013 of the study period.

- In comparison with regard to overall growth index rates, as far as Life insurance penetration is concerned, Taiwan $(240.46 \%)$ is in first;Hong Kong (228.07\%) in second;India(144.19\%)in third positions

- With IRDA's continuous monitoring of Insurance business of both public and private insurance companies and implementation of regulatory practices like penalties etc. public awareness and confidence in life insurance business are being improved.

- The number of life insurance offices has also increased from 2199 in the year 2001 to 12018 in the year 2010 and decreased a little in number in later years.

\section{Suggestions}

- Insurance density and penetration, though improved to a considerable extent when compared to the past levels, they 
are still to be improved to much more extent to cater the insurance needs of the people.

- Many more consumer education programs are to be conducted and projected by IRDA through different kinds of media to bring awareness and proper understanding about the need for insurance among the people and about the benefits and risk factors of policies that they are taking.

- Most of the Unit Linked Insurance policyholders are losing a major part of even actual amounts of their paid premiums when they withdraw money due to unexpected falls in the stock market. Majority of these people don't know about the risk factors of these policies. Just for the sake of commission or to fulfil their business targets, insurance agents indulge in the misselling of insurance products. IRDA is to focus much attention on this and try to educate the policyholders about market risks and fund maintenance charges and control the selling of wrong products.

\section{Conclusion}

During the period before the establishment of Insurance Regulatory and Development Authority and the entry of private life insurers, the insurance density and penetration were low. After the establishment of Insurance Regulatory and Development Authority, development along with growth in Indian insurance sector is accelerated. Quality enhancement in services, assurance in claimsettlement,least possibility for misselling by insurers, Increasing number of insurance offices even in rural areas, speedier improvement of insurance density and penetration by bringing awareness in public through consumer education programs have helped increase insurance penetration. Continuousmonitoringand implementation of timely regulations and penalties for violation by IRDA and the ultimate aim of "promoting insurance and protecting the insured" havealso become possible to a considerable extent.Still there is a lot of road ahead for IRDA to move forward with increased means to safeguard the rights and benefits of customers/policyholders and capture the increasing insurance growth potential. All the life 
insurance companies too should also focus on innovations in designing insurance products for various groups of people rather than selling the wrong products just to boost up sales.

\section{References}

Batra, G. (2005). Financial Service and Markets. New Delhi: Deep and Deep.

Ganguly, A. (2002). Insurance Management. New Delhi: New Age International Publishing House.

Gupta, S. P. (2010).Statistical methods. New Delhi: S Chand and Co.

ICFAI. (2002). Insurance underwriting: A Managerial Perspective.

IRDA.(2001-2014). IRDA. Annual Report. Retrieved from: Www.IRDA.gov.in

LIC. (2001-2014). LIC. Annual Report. Retrieved from: www.licindia.in

Mishra, B. (2007). Investment decision making process by employed women. Jalandhar, Punjab: Mahamaya Publishing.

Preetsingh.(2008). Investment Management Security Analysis and Portfolio Management.Mumbai, Maharashtra: Himalaya Publishing House.

Ranganadhachari, A. V. (2003). Banking Financial System. Mumbai: Kalyani Publishing House.

Satyadevi, C. (2009). Business Statistics. New Delhi: S Chand and Co.

Singh, A. K., \& Singh, M. (2014). Indian life insurance industry changing scenario and need for innovation. Journal of Social and Economic Policy, 11(1), 103-108.

Venkataramani, K., Kumar, R. M. \& Brinda, G. (2015).A study on the attitude of consumers and insurance agents towards the proposed increase in Foreign Direct Investment (FDI) in the insurance sector in India. International Journal of Scientific and Research Publications, 5(2). 